Cite this: RSC Adv., 2022, 12, 3871

Received 15th November 2021

Accepted 24th January 2022

DOI: 10.1039/d1ra08373b

rsc.li/rsc-advances
Check for updates

\section{DNA aptamer-based dual-responsive nanoplatform for targeted MRI and combination therapy for cancer $\dagger$}

\author{
Mingming Zhao, ${ }^{\text {ab }}$ Xiaoxi Song, ${ }^{\text {ab }}$ Jiahui Lu, ${ }^{\text {b }}$ Siwen Liu, ${ }^{b}$ Xuan Sha, ${ }^{\text {b }}$ Qi Wang, ${ }^{\text {ab }}$ \\ $\mathrm{Xu} \mathrm{Cao,}{ }^{b}$ Kai Xu*ab and Jingjing Li (D) *ab
}

\begin{abstract}
Accurate drug delivery is a common topic, and it has always been an aim that scientists strive to achieve. To address this need, multifunctional and stimulus-sensitive nanoplatforms have attracted significant attention. Here we fabricated a glutathione (GSH) and adenosine- $5^{\prime}$-triphosphate (ATP) dual-sensitive nanoplatform for controlled drug release and activatable MRI of tumors based on DNA aptamer and manganese dioxide $\left(\mathrm{MnO}_{2}\right)$ nanosheets. Cleverly utilizing the DNA tunability, AS1411 aptamer which binds nucleolin, a protein specifically expressed on tumor-associated endothelial cells, was designed with ATP aptamer and its CDNA to load the anticancer drug, doxorubicin (Dox). The formed DNA-Dox complex was delivered to the tumor region with the help of $\mathrm{MnO}_{2}$ nanosheets and AS1411 aptamer. Then, the on-demand drug release in tumor cells was realized with the co-effect of the ATP aptamer and GSH reduction. It was found that without the structure of the $\mathrm{MnO}_{2}$ nanosheets being broken by GSH, Dox almost could not be released even in the presence of ATP. Similarly, without ATP, Dox was still maintained in the duplex even with GSH. Further combining the MRI ability and chemodynamic therapy of the produced $\mathrm{Mn}^{2+}$, an improved effect of the inhibition of tumor growth and imaging was achieved. Our designed DNA aptamer-based dualresponsive nanoplatform can realize the targeted drug delivery and MRI of breast tumor cells both in vitro and in vivo.
\end{abstract}

\section{Introduction}

Accurate drug delivery plays an important role in improving the therapeutic effect and reducing side effects. Particularly, with the good development of nanotechnology, a series of nanomaterial-based drug delivery systems have emerged. Dendrimers with micellar solubilization, good encapsulation ability, biodegradable nature and excellent biocompatibility have been widely used for drug delivery. ${ }^{1}$ Biopolymeric nanoparticles such as chitosan and dextran, liposomes, ${ }^{2,3}$ mesoporous silica, ${ }^{4}$ gold nanomaterials, ${ }^{5}$ carbon nanomaterials, ${ }^{6}$ protein $s^{7}$ and even cells ${ }^{8}$ have been employed for drug delivery. The introductions of aptamers as targeting ligands to the above drug delivery systems further favor the accurate treating and diagnosing of disease. The characteristics of aptamers with high affinity and specificity for their targets, small size for little influence on the drug delivery device, and synthesized chemically for easy conjugation with nanocarrier or imaging

${ }^{a}$ School of Medical Imaging, Xuzhou Medical University, Xuzhou 221004, P. R. China. E-mail:qingchao0124@163.com

${ }^{b}$ Department of Radiology, Affiliated Hospital of Xuzhou Medical University, Xuzhou 221006, P. R. China

$\dagger$ Electronic supplementary information (ESI) available. See DOI: 10.1039/d1ra08373b molecules enable their applications in the therapy and diagnosis of disease, especially tumors. ${ }^{9}$ AS1411 is a 26-nucleotide guanosine-rich DNA aptamer that can bind to the nucleolin proteins on tumor cells. ${ }^{10-12}$ It can be used for targeted drug delivery and imaging. Dai et al. constructed multifunctional nanoparticles through AS1411 aptamer-conjugated mesoporous polydopamine for targeted and synergistic chemotherapy/ photothermal therapy of prostate cancer. ${ }^{13}$ Chen et al. reported an aptamer-dendrimer functionalized magnetic nanooctahedrons for AS1411 aptamer-targeted, NIR/MR dualmodality imaging guided, and HSP70/HSP90 silencing sensitized magnetochemotherapy. ${ }^{14}$ To realize the on-demand release, a series of tumor related stimulus have been employed to design stimuli-triggered drug delivery systems. A series of endotrigger stimulies, such as $\mathrm{pH},{ }^{15}$ hypoxia, ${ }^{16}$ enzyme, ${ }^{17}$ temperature, ${ }^{18}$ redox, ${ }^{19,20}$ glucose ${ }^{21,22}$ and other exotrigger stimuli such as light, ${ }^{23}$ electric, ${ }^{24}$ magnetic, ${ }^{25}$ and ultrasound $^{26}$ responsive drug delivery systems have been well documented. ${ }^{27}$ For the design of these stimuli-triggered drug delivery systems, DNA molecules have been shown to be excellent substrates for the design and construction of intelligent vehicles for imaging and cargo delivery. Zhao et al. fabricated an autonomous DNA robot with a DNA aptamer binding with nucleolin and the blood coagulation protease thrombin. The nucleolin-targeting aptamer triggered the mechanical opening 
of the DNA nanorobot and exposed the thrombin inside to activate coagulation at the tumor site. ${ }^{28} \mathrm{Gu}$ et al. developed a nanogel containing ATP aptamer and hyaluronic acid for active tumor-targeting and ATP triggered drug release. ${ }^{29}$ Fan et al. reviewed the DNA nanotechnology-enabled drug delivery systems, showing a lot of state-of-the-art strategies for the construction of DNA nanostructures and drug payloads delivered by DNA nanovehicles. ${ }^{30}$ Inspired by these successful applications of DNA-based nanovehicles, we tried to design strategy for the possibility of combining more than one stimuli for much greater targeted imaging and more efficient drug delivery as well as the integration of the imaging and combination therapy to further improve the theranostic effect of tumor.

To realize this aim, in this work we designed a dualresponsive nanoplatform comprised of DNA scaffold and $\mathrm{MnO}_{2}$ nanosheets. The DNA scaffold was designed to contain AS1411 aptamer as targeting molecule, ATP aptamer and its cDNA for Dox loading and ATP triggered drug release (Scheme 1). Due to the different concentrations in the extracellular environment $(<0.4 \mathrm{mM})$ and in the intracellular cytosol (1-10 $\mathrm{mM}$ ), ATP has been applied as a trigger for drug release control. ${ }^{29,31}$ Specifically, the GC pairs of the duplex of ATP aptamer and its cDNA provided loading sites for Dox and ATPtriggered Dox release. $\mathrm{MnO}_{2}$ nanosheets were employed as the activatable MRI nano contrast agent, chemodynamic therapy (CDT) agent, and the GSH triggered drug delivery nanoplatform to load the functional DNA scaffold with Dox through coordination interaction between phosphate backbone of DNA and $\mathrm{MnO}_{2}$ nanosheets. In tumor, nucleolin-medicated endocytosis by AS1411 aptamer realized the internalization of our fabricated nanoplatform to tumor cells. Then, the overexpressed GSH reduced $\mathrm{MnO}_{2}$ nanosheets to $\mathrm{Mn}^{2+}$ and the broken up of the nanosheet structure favored the release of loaded functional DNA scaffold. The produced $\mathrm{Mn}^{2+}$ can further light up MRI signal and mediated Fenton-like reactions for CDT. Later, a significantly higher ATP level in the cytosol compared with the extracellular fluid brought the binding between ATP and its aptamer to cause the structure change of DNA scaffold and the release of Dox eventually. The on-demand intracellular drug release significantly increased the amount of subsequently accumulated Dox in the nuclei beyond the threshold. Finally, the dual-response mediated drug delivery and combination of CT and CDT were realized with MRI monitoring. The coexistence of GSH and ATP could produce the maximum therapeutic effect.

\section{Experimental section}

\subsection{Materials, cell line and animals}

Manganese chloride tetrahydrate $\left(\mathrm{MnCl}_{2} \cdot 4 \mathrm{H}_{2} \mathrm{O}\right)$, tetramethylammonium hydroxide (TMAH), hydrogen peroxide $\left(\mathrm{H}_{2} \mathrm{O}_{2}\right)$ and ethanol were purchased from Aladdin Biochemical Polytron Technologies, Inc. (Shanghai, China). DNA oligos were obtained from Sangon Biotech Co. Ltd (Shanghai, China). Doxorubicin was obtained from Kangmei Biotechnology Co., Ltd (Xuzhou, China). All chemicals involved in this work were analytical grade. All aqueous solutions were prepared with ultrapure water ( $\geq 18 \mathrm{M} \Omega$, Milli-Q, Millipore). The MDA-MB-231 breast cancer cells and mouse NIH-3T3 fibroblasts cells were obtained from the Cell Bank of the Chinese Academy of Sciences (Shanghai, China). Incomplete medium, fetal bovine serum and penicillin-streptomycin solution were added to a sterile culture flask in a ratio of $100: 10: 1$, and formulated into a fully medium and stored in a $4{ }^{\circ} \mathrm{C}$ refrigerator. Cells were cultured at $37^{\circ} \mathrm{C}, 5 \% \mathrm{CO}_{2}$ incubator (Thermo, USA). The BALB/c mice were purchased from Xuzhou Medical University Animal Experiment Center (Xuzhou, China). Animal experiments were performed in accordance with the National Institutes of Health guidelines on the use of animals in research, and all animal experiments were approved by the Animal Care Committee of the Xuzhou Medical University (no. 202007W001).

\subsection{Apparatus and characterization}

KS-180EI medical ultrasonic cleaning machine was used to redisperse $\mathrm{MnO}_{2}$ powder (Ningbo, China). Atomic force microscopy (AFM) (SP13800, Japan) and transmission electron microscopy (TEM) (TEC-NAI G2, USA) were used to get size and morphology characterizations. Nano ZS90 (Malvern, England) was employed to determine the zeta potential. The UV-vis absorption spectra were observed by the UH4150 spectrophotometer (Techcomp, China). LS 55 Fluorescence Spectrometer (PerkinEimer, USA) was used to get fluorescence spectra. The $\mathrm{Mn}^{2+}$ concentration was measured by inductively coupled plasma-mass spectrometry (ICP-MS) (PerkinElmer, USA). In vitro and in vivo MRI scans were performed on a $3.0 \mathrm{~T} \mathrm{MR}$ imaging system (GE Discovery 750w) using a small animal coil. An inverted fluorescence microscope (Olympus bx 51, Japan) was used to observed histological changes of related organs of mice and cellular morphology.

\subsection{Preparation of $\mathrm{MnO}_{2}$ nanosheets}

$\mathrm{MnO}_{2}$ nanosheets were prepared according to previous reports. ${ }^{32}$ Briefly, $0.5937 \mathrm{~g} \mathrm{MnCl}_{2} \cdot 4 \mathrm{H}_{2} \mathrm{O}$ was dissolved in $10 \mathrm{~mL}$ $\mathrm{H}_{2} \mathrm{O}$. Then $20 \mathrm{~mL} 3 \% \mathrm{H}_{2} \mathrm{O}_{2}$, and $2.172 \mathrm{~g}$ hydroxylated TMAH were added. The solution immediately turned dark brown and stirred violently overnight at room temperature in the open air. The overnight reactants were centrifuged, and the supernatant was removed. The obtained precipitate was washed twice with ultra-pure water and methanol respectively. The precipitate was then placed in a vacuum constant temperature drying box and dried at $40{ }^{\circ} \mathrm{C}$. The dried powder was dissolved in ultra-pure water with $40 \mathrm{~mL}$ per $10 \mathrm{mg}$ and treated with ultrasonic for 12 hours. Finally, the liquid was centrifuged and filtered with a filter head with a pore diameter of $0.2 \mu \mathrm{m}$ to collect $\mathrm{MnO}_{2}$ nanosheets solution.

\subsection{Preparation of $\mathrm{NH}_{2}$-Probe 1-cDNA-Dox@ $\mathrm{MnO}_{2}$}

2.4.1 The influence of amino group modification on the DNA loading ability of $\mathbf{M n O}_{2}$ nanosheets. To evaluate the loading ability of $\mathrm{MnO}_{2}$ nanosheets to Probe 1-cDNA, Probe 1cDNA-Dox as well as the influence of amino group on the loading amount, Probe 1 was modified with fluorophore 


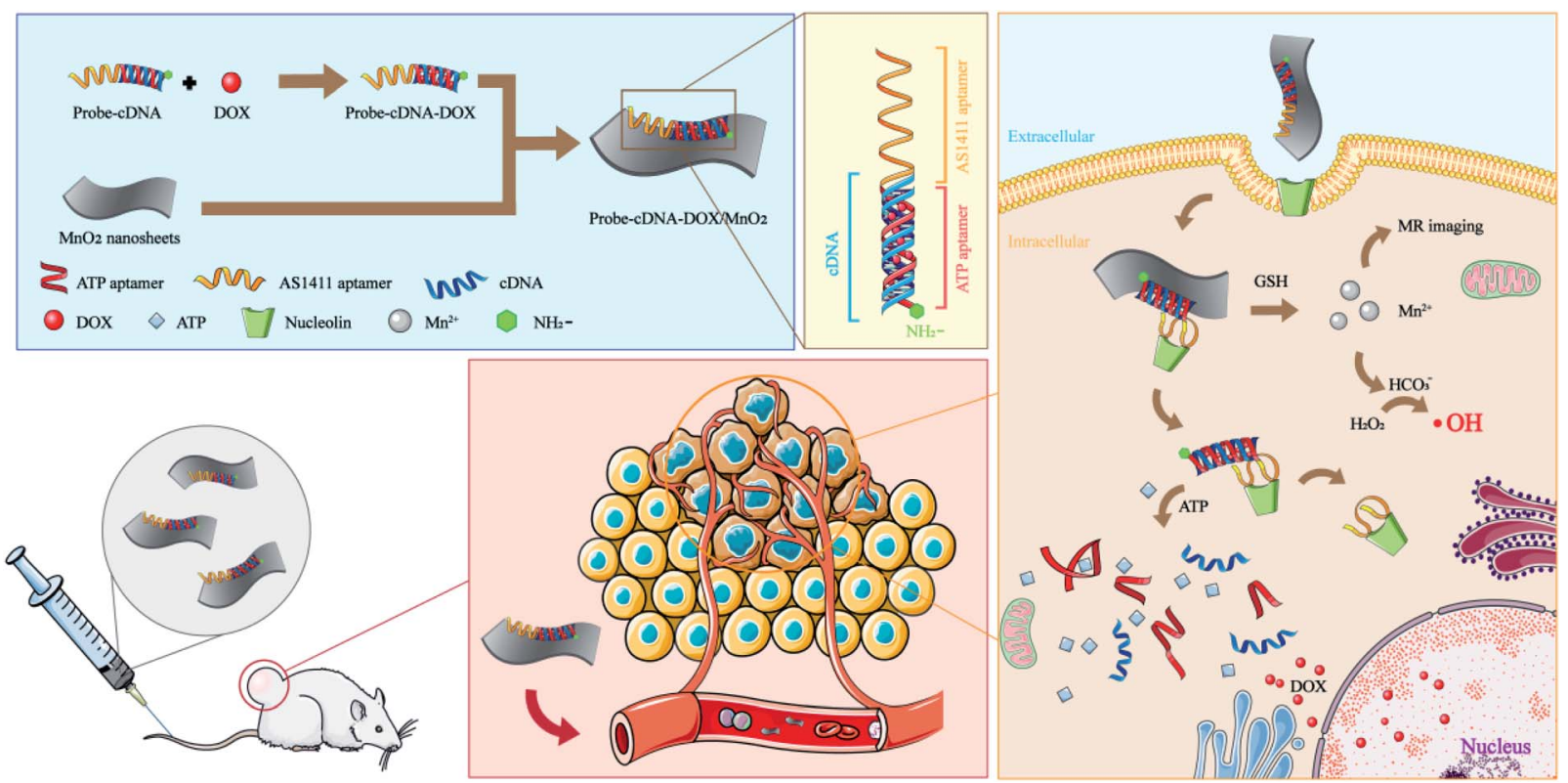

Scheme 1 Schematic illustration of the construction of $\mathrm{NH}_{2}$-Probe 1-cDNA-Dox@MnO 2 nanoplatform and their application for MRI and combination therapy of tumor.

fluorescein (FAM) and amino group, respectively. The adsorption of FAM-Probe 1 and FAM- $\mathrm{NH}_{2}$-Probe 1 on $\mathrm{MnO}_{2}$ nanosheets was first investigated. $100 \mu \mathrm{L} \mathrm{MnO}_{2}$ nanosheets $(15.3 \mathrm{mM}$ $\mathrm{Mn})$ were incubated with $5 \mu \mathrm{L}, 10 \mu \mathrm{L}, 20 \mu \mathrm{L}, 30 \mu \mathrm{L} 25 \mu \mathrm{M}$ FAMProbe 1 or $\mathrm{FAM}-\mathrm{NH}_{2}$-Probe 1 with a final volume of $300 \mu \mathrm{L}$. Thirty minutes later, the solution was collected for fluorescence test. The fluorescence intensity of $5 \mu \mathrm{L}, 10 \mu \mathrm{L}, 20 \mu \mathrm{L}, 30 \mu \mathrm{L} 25$ $\mu$ M FAM-Probe 1 or FAM- $\mathrm{NH}_{2}$-Probe 1 dissolved in $\mathrm{H}_{2} \mathrm{O}$ with a final volume of $300 \mu \mathrm{L}$ were measured as control.

2.4.2 The influence of hybridization on the adsorption of DNA probes on $\mathrm{MnO}_{2}$ nanosheets. To evaluate the influence of the hybridization between FAM- $\mathrm{NH}_{2}$-Probe 1 and cDNA on their adsorption on $\mathrm{MnO}_{2}$ nanosheets, $20 \mu \mathrm{L} 25 \mu \mathrm{M}$ cDNA were mixed with $20 \mu \mathrm{L} 25 \mu \mathrm{M}$ FAM- $\mathrm{NH}_{2}$-Probe 1 and incubated for $30 \mathrm{~min}$ to form FAM- $\mathrm{NH}_{2}$-Probe 1-cDNA. Then, the duplex were mixed with $100 \mu \mathrm{L} \mathrm{MnO}_{2}$ nanosheets $(15.3 \mathrm{mM} \mathrm{Mn})$ with a final volume of $300 \mu \mathrm{L}$. After $30 \mathrm{~min}$ incubation, their fluorescence emissions were detected. The fluorescence emissions of $\mathrm{MnO}_{2}$ nanosheets, FAM- $\mathrm{NH}_{2}$-Probe 1 and FAM- $\mathrm{NH}_{2}$-Probe 2-cDNA with $\mathrm{MnO}_{2}$ nanosheets at the same concentrations were also detected for comparision.

2.4.3 The loading of Dox by $\mathbf{N H}_{2}$-Probe 1-cDNA and $\mathbf{N H}_{2}-$ Probe 2-cDNA. The $\mathrm{NH}_{2}$-Probe 1-cDNA or $\mathrm{NH}_{2}$-Probe 2-cDNA were incubated with Dox with a variety of ratios $(0,0.01,0.025$, $0.05,0.1,0.25,0.5,1,1.5)$ for $30 \mathrm{~min}$ at $37^{\circ} \mathrm{C}$, where the Dox concentration was fixed at $1.33 \mu \mathrm{M}$ and the final volume of solution was $300 \mu \mathrm{L}$. With the loading of Dox to the $\mathrm{NH}_{2}$-Probe 1-cDNA or $\mathrm{NH}_{2}$-Probe 2-cDNA, the fluorescence emissions of Dox would be quenched. Thus, the fluorescence emissions of Dox were recorded to determine the loaded Dox on DNA scaffolds with LS 55 Fluorescence Spectrometer (PerkinEimer, USA).

2.4.4 Preparation of $\mathbf{N H}_{2}$-Probe 1-cDNA-Dox@ $\mathrm{MnO}_{2}$. The Dox-loaded ATP-responsive and nucleolin protein-binding DNA duplex $\left(\mathrm{NH}_{2}\right.$-Probe 1-cDNA-Dox) was prepared by incubating Dox with a hybridized duplex of Probe 1 containing AS1411 aptamer and ATP aptamer and its CDNA at a molar ratio of $1: 1$ for $30 \mathrm{~min}$. Then, they were incubated with $\mathrm{MnO}_{2}(20 \mu \mathrm{L}$, $15.3 \mathrm{mM} \mathrm{Mn})$. The final volume of $\mathrm{NH}_{2}$-Probe 1-cDNADox@MnO 2 was fixed to be $300 \mu \mathrm{L}$ with ultrapure water.

\subsection{The release of Dox triggered by ATP}

The release of Dox from $\mathrm{NH}_{2}$-Probe 1-cDNA-Dox triggered by ATP was monitored by the fluorescence changes of Dox. Briefly, $\mathrm{NH}_{2}$-Probe 1-cDNA-Dox was incubated with different ATP concentrations $(0,0.2,0.4,1,2,4,6,8,10 \mathrm{mM})$ for $30 \mathrm{~min}$. Then, the changes of Dox fluorescence were recorded. The released Dox from ATP-triggered $\mathrm{NH}_{2}$-Probe 2-cDNA-Dox were also determined to evaluate the influence of the existence of AS1411 aptamer on the Dox release.

\subsection{The dual-responsive release of Dox from $\mathrm{NH}_{2}$-Probe 1- cDNA-Dox@ $\mathrm{MnO}_{2}$}

To evaluate the effect of the presence of GSH and ATP on the release of Dox, the fluorescence emissions of $\mathrm{NH}_{2}$-Probe 1cDNA-Dox@ $\mathrm{MnO}_{2}$ in the presence of ATP, GSH or ATP + GSH were detected. Briefly, $16 \mu \mathrm{L} 25 \mu \mathrm{M} \mathrm{NH}_{2}$-Probe 1 was hybridized with $16 \mu \mathrm{L} 25 \mu \mathrm{M}$ cDNA for 30 minutes. Then, $10 \mu \mathrm{L} 40 \mu \mathrm{M}$ Dox was added and incubated for 30 minutes to obtain $\mathrm{NH}_{2}$-Probe 1cDNA-Dox. Different amount of $\mathrm{MnO}_{2}(0,10,20,50 \mu \mathrm{L}$ Mn 15.3 $\mathrm{mM}$ ) was introduced and incubated for 30 minutes, respectively. The fluorescence changes of Dox were measured after the above solution was mixed with $10 \mathrm{mM}$ ATP, $10 \mathrm{mM}$ GSH or $10 \mathrm{mM}$ ATP + $10 \mathrm{mM} \mathrm{GSH}$ for 30 minutes. 


\subsection{Relaxivity calculation of $\mathrm{MnO}_{2}$ and $\mathrm{NH}_{2}$-Probe 1-cDNA- Dox@ $\mathrm{MnO}_{2}$ with GSH}

The Mn concentration was detected according to ICP-MS. In the presence of GSH, the solution with manganese ion concentration of 0-1.2 mM was prepared respectively. The corresponding linear regression equation graph was made with the concentration of manganese ion as the horizontal coordinate and the reciprocal of $T_{1}$ relaxation time of samples with different concentrations as the vertical coordinate (Fig. 6B). The $T_{1}$ relaxation rates of the $\mathrm{MnO}_{2}$ and $\mathrm{NH}_{2}$-Probe 1-cDNADox@ $\mathrm{MnO}_{2}$ were compared. The scanning parameters were setted as follows: repetition time $(\mathrm{RT})=425 \mathrm{~ms}$, echo time (TE) $=\min$ full, matrix size $=384 \times 224$, field of view $(\mathrm{FOV})=18 \mathrm{~cm}$ $\times 18 \mathrm{~cm}$, slice thickness $=3.0 \mathrm{~mm}$, spacing $=1.5 \mathrm{~mm} .{ }^{33}$

\subsection{Evaluation of drug release}

The $\mathrm{NH}_{2}$-Probe 1-cDNA-Dox@ $\mathrm{MnO}_{2}$ solution was packaged in a dialysis bag with a molecular weight cut-off of 3500-5000 Da. It was placed in a test tube fitted with a $3 \mathrm{~mL}$ release buffer solution, containing $5 \mathrm{mM}$ HEPES, $137 \mathrm{mM} \mathrm{NaCl}, 10 \mathrm{mM}$ $\mathrm{MgCl}_{2}, 10 \mathrm{mM}$ ATP and $10 \mathrm{mM}$ GSH. Magnetical stirring was performed at $37^{\circ} \mathrm{C}$. At each scheduled time (0, 15, 30, 40, 50, 70, $90,120,150,200,300 \mathrm{~min}), 300 \mu \mathrm{L}$ release medium was taken out for fluorescence test. The buffer volume was maintained at $3 \mathrm{~mL}$ all the time.

\subsection{MRI stability}

The $\mathrm{NH}_{2}$-Probe 1-cDNA-Dox@ $\mathrm{MnO}_{2}$ solution was stored in a refrigerator at $4{ }^{\circ} \mathrm{C}$. At 0 day, 1 day, 5 day, 10 day, 15 day, 20 day, 30 day, the change of $T_{1}$ signal intensity in the presence of GSH was measured.

\subsection{In vitro and in vivo toxicity test}

The in vitro cytotoxicity tests were performed using MTT assay ${ }^{34}$ on MDA-MB-231 (breast cancer cell line) and NIH-3T3 (mouse fibroblasts cells). Briefly, cells in the logarithmic growth phase were evenly inoculated on the 96-well culture plate with a total number of $0.5 \times 10^{5}$ cells per well. The cells were cultured for 24-36 h to become overgrown. Subsequently, $\mathrm{NH}_{2}$-Probe 1cDNA-Dox, $\mathrm{NH}_{2}$-Probe 1-cDNA@ $\mathrm{MnO}_{2}$, and $\mathrm{NH}_{2}$-Probe 1-cDNADox@ $\mathrm{MnO}_{2}$ with various $\mathrm{NH}_{2}$-Probe 1-cDNA concentrations were introduced. After incubation for $24 \mathrm{~h}$, the cells were washed with PBS for 3 times. Then, $100 \mu \mathrm{L} 1 \mathrm{mg} \mathrm{mL}{ }^{-1}$ MTT was added and incubated for another $4 \mathrm{~h}$. After discarding the supernatant, $100 \mu \mathrm{L}$ DMSO was added to each well. The absorbance value of each well at $490 \mathrm{~nm}$ was measured with a microplate analyzer, and the average absorbance value of each group was calculated.

The experiment of live and dead cell observations was also introduced to evaluate the toxicity and in vitro therapy effect. In brief, the MDA-MB-231 cells were co-cultured with $\mathrm{NH}_{2}$-Probe 1cDNA@ $\mathrm{MnO}_{2}$ and $\mathrm{NH}_{2}$-Probe 1-cDNA-Dox@ $\mathrm{MnO}_{2}$ at the equivalent concentration of $\mathrm{NH}_{2}$-Probe 1-cDNA for $2 \mathrm{~h}$. After that, the cells were washed and incubated with calcein acetoxymethyl ester (CA) $(4 \mu \mathrm{M})$ and propidium iodide (PI) $(4 \mu \mathrm{M})$ staining reagents for $10 \mathrm{~min}$ and then observed using an inverted fluorescence microscope.

Intravenous injection of $\mathrm{NH}_{2}$-Probe 1-cDNA-Dox@ $\mathrm{MnO}_{2}$ was used to observe the histological changes of the heart, liver, spleen, kidney, lung of mice, and to evaluate the toxicity of $\mathrm{NH}_{2}$ Probe 1-cDNA-Dox@ $\mathrm{MnO}_{2}$ in vivo. $200 \mu \mathrm{L} \mathrm{NH} \mathrm{NH}_{2}$-Probe 1-cDNADox@ $\mathrm{MnO}_{2}$ (3.06 mM Mn) was injected into the mice via the tail vein. The mice were sacrificed at day 1, 7 and 21 post-injection and the heart, liver, spleen, lung, kidney and other organs were taken out, fixed with $10 \%$ formalin for 3 days and stained with hematoxylin and eosin $(\mathrm{H} \& \mathrm{E})$. The tissue structure was observed under a microscope. Untreated mice were dissected as controls.

Hematological and biochemical analyses were also used to evaluate the in vivo toxicity of $\mathrm{NH}_{2}$-Probe 1-cDNA-Dox@ $\mathrm{MnO}_{2}$. Twenty-four Kunming mice were divided into 4 groups. Six mice in group 0 day were injected with normal saline and eighteen mice in group 1 day, 7 day and 21 day were injected with $\mathrm{NH}_{2}$ Probe 1-cDNA-Dox@ $\mathrm{MnO}_{2}(200 \mu \mathrm{L}$ of $3.06 \mathrm{mM} \mathrm{Mn})$ through tail vein, respectively. At the time point ( 0 day, 1 day, 7 day and 21 day), the blood samples from mice in the corresponding group were collected by eyeball extirpating for blood routine and biochemical analyses $(n=3)$.

\subsection{Blood half-life determination}

The $\mathrm{NH}_{2}$-Probe 1-cDNA-Dox@ $\mathrm{MnO}_{2}$ solution $(200 \mu \mathrm{L}, 3.06 \mathrm{mM}$ $\mathrm{Mn})$ was injected into the mice through a tail vein. The blood samples $(40 \mu \mathrm{L})$ were collected at different time periods $(15 \mathrm{~min}$, $30 \mathrm{~min}, 45 \mathrm{~min}, 1 \mathrm{~h}, 2 \mathrm{~h}, 4 \mathrm{~h}, 6 \mathrm{~h}, 12 \mathrm{~h}$ ) post-injection. The collected blood was thoroughly mixed with nitric acid solution. After digestion at $80{ }^{\circ} \mathrm{C}$ for $30 \mathrm{~min}$, the concentrations of $\mathrm{Mn}$ in each sample were determined by ICP-MS. Fitting half-life curve and half-life $\left(T_{1 / 2}\right)$ was calculated with Origin 8.0 software.

\subsection{In vitro and in vivo specific MRI}

For in vitro MRI, MDA-MB-231 breast cancer cells were first cultured overnight on a 6 -well plate at a density of $2 \times 10^{5}$ cells per well. Then, different concentrations of $\mathrm{NH}_{2}$-Probe 1-cDNADox@ $\mathrm{MnO}_{2}$ or $\mathrm{NH}_{2}$-Probe 2-cDNA-Dox@ $\mathrm{MnO}_{2}(0.26 \mathrm{mM}$, $0.51 \mathrm{mM}, 1.02 \mathrm{mM} \mathrm{Mn}$ ) were co-incubated with cells for $2 \mathrm{~h}$. Subsequently, the cells were washed twice with fresh PBS, and digested with EDTA-trypsin. The collected cells were dispersed in a $1 \%$ agarose gel for MRI scanning.

A $100 \mu \mathrm{L}$ cell suspension containing $2 \times 10^{6}$ MDA-MB-231 breast cancer cells was injected into the subcutaneous soft tissue on the right dorsum axillary of BALB/c female nude mice. When the tumor diameter reached about $5 \mathrm{~mm}$, MDA-MB-231 nude mice were used for MRI. In vivo MRI was performed on the MDA-MB-231 nude mice before ( $0 \mathrm{~min}$ ) and post-injection (10 min, $30 \mathrm{~min}, 1 \mathrm{~h}, 2 \mathrm{~h}, 3 \mathrm{~h}, 6 \mathrm{~h}, 12 \mathrm{~h}, 24 \mathrm{~h}$ ) of $\mathrm{NH}_{2}$-Probe 1cDNA-Dox $/ \mathrm{MnO}_{2}$ or $\mathrm{NH}_{2}$-Probe 2-cDNA-Dox/MnO $(200 \mu \mathrm{L}$, $3.06 \mathrm{mM} \mathrm{Mn}$ ) using an animal $\mathrm{T} / \mathrm{R}$ coil on a $3.0 \mathrm{~T}$ magnetic resonance imaging system (GE Discovery 750W, USA). The change of signal intensity in the tumor with the time passing by was recorded accordingly. The $T_{1}$-weighted MR images were obtained using a gradient echo (GRE) sequence with the 
following parameters, repetition times $(\mathrm{TR})=16 \mathrm{~ms}$, echo time $(\mathrm{TE})=3.2 \mathrm{~ms}$, field of view $(\mathrm{FOV})=8 \mathrm{~cm} \times 8 \mathrm{~cm}$, matrix size $=$ $320 \times 288$, slice thickness $=0.4 \mathrm{~mm}$, and spacing $=0.5 \mathrm{~mm} .^{35}$

\subsection{OH generation of $\mathrm{NH}_{2}$-Probe 1-cDNA-Dox@ $\mathrm{MnO}_{2}$ in the presence of GSH}

Chemodynamic therapy of $\mathrm{NH}_{2}$-Probe 1-cDNA-Dox/ $\mathrm{MnO}_{2}$ was dependent on their ability to generate $\cdot \mathrm{OH}$ in tumor microenvironment. $\cdot \mathrm{OH}$ degrades methylene blue $(\mathrm{MB})$, and $\cdot \mathrm{OH}$ induced degradation of $\mathrm{MB}$ is monitored by absorbance change at $665 \mathrm{~nm}$. Briefly, $25 \mathrm{mM} \mathrm{NaHCO}$ containing $\mathrm{NH}_{2}$-Probe 1cDNA-Dox $/ \mathrm{MnO}_{2}(15.3 \mathrm{mM} \mathrm{Mn})$ and $1 \mathrm{mM}$ GSH was first shaken for $15 \mathrm{~min}$. Then, $10 \mu \mathrm{g} \mathrm{mL}{ }^{-1} \mathrm{MB}$ and $8 \mathrm{mM} \mathrm{H}_{2} \mathrm{O}_{2}$ were added to the above solution with a final volume of $300 \mu \mathrm{L}$. After incubated at $37^{\circ} \mathrm{C}$ for $30 \mathrm{~min}$, the absorbance of MB at $665 \mathrm{~nm}$ was determined.

\subsection{In vivo therapy}

The inhibitory effect of MDA-MB-231 on tumor growth in BALB/ c nude mice was evaluated. $\mathrm{NH}_{2}$-Probe 1-cDNA-Dox@ $\mathrm{MnO}_{2}$ or $\mathrm{NH}_{2}$-Probe 2-cDNA-Dox/ $\mathrm{MnO}_{2}$ were injected intravenously (i.v.) 7 times at a dose of $200 \mu \mathrm{L} 3.06 \mathrm{mM}$ Mn with a 3 day-interval, respectively. PBS was used as the control. Tumor length and width were recorded with a vernier caliper every 3 days for 21 days. The volume of the tumor was calculated by the formula: volume $=$ width $^{2} \times$ length/2. On the last day, MRI scans were performed on the tumor-bearing nude mice. The body weight of the nude mice during the above treatment was recorded every three days.

\subsection{Statistical analysis}

SPSS 22.0 software package was used for statistical analysis. One-way ANOVA and Dunnettt-tests were used to compare the statistical significance among different groups. Quantitative data conform to normal distribution and are expressed as mean \pm SD. According to the test level $\alpha=0.05, p<0.05$ was considered statistically significant.

\section{Results and discussion}

\subsection{DNA scaffold design}

In this work, we aim to fabricate the tumor microenvironment dual-responsive nanoplatform for MRI and combination therapy of tumor based on DNA scaffold and $\mathrm{MnO}_{2}$ nanosheets. To realize this aim, a DNA sequence named Probe 1 containing ATP aptamer and AS411 aptamer sequence was first designed (Table S1 $\dagger$ ). ATP aptamer still maintained the second structure with the addition of AS1411 aptamer (Fig. S1A $\dagger$ ). To load Dox, a partial complementarity cDNA sequence was introduced to hybridize with Probe 1 . The formed duplex had a 27-base pair with GC-rich motif which could be used for anthracyclinecontained Dox loading. ${ }^{36}$ To evaluate the amount of Dox molecules loaded into the Probe 1-cDNA duplex, the changes of Dox fluorescence were monitored before and after intercalation. As shown in Fig. 1A, when the concentration of Dox was fixed, the fluorescence intensity of Dox was decreased with an increasing molar ratio of the Probe 1-cDNA duplex, indicating more Dox molecules were loaded onto the duplex due to the initiation of forster resonance energy transfer (FRET) between Dox molecules and the DNA duplex. ${ }^{37}$ A maximum quenching efficacy was achieved when the molar ratio of duplex to Dox was 1 . Furthermore, the existence of ATP could trigger the release of Dox and the release amount was increased with the ATP concentration raise (Fig. 1B), showing the possibility of the ATP triggered drug release. We also compared the Dox loading and ATP triggered drug release without AS1411 aptamer. As shown in Fig. S1B and $\mathrm{C}, \dagger$ such binding and releasing property was not influenced by the existence of AS1411 aptamer, favoring the specific targeting and drug delivery of the nanoplatform to tumor.

\subsection{Characterization of $\mathrm{MnO}_{2}$ nanosheets and $\mathrm{NH}_{2}$-Probe 1- cDNA-Dox@ $\mathrm{MnO}_{2}$}

The $\mathrm{MnO}_{2}$ nanosheets were employed as nanocarrier and activatable MRI contrast agent as well as the chemodynamic therapy agent in this work. The $\mathrm{MnO}_{2}$ nanosheets have a wide UV-vis absorption peak at $300-800 \mathrm{~nm}$, and the characteristic absorption center is located at $360 \mathrm{~nm}$ (Fig. 1C). ${ }^{32}$ Their hydrodynamic diameters were $161.2 \mathrm{~nm}$ (Fig. 1D). TEM images revealed that $\mathrm{MnO}_{2}$ nanosheets exhibited a typical twodimensional morphology with occasional folds and wrinkles (Fig. 1E) and a brown, transparent liquid under the white light (Fig. S2A $\dagger$ ) with a thickness of approximately $1.5 \mathrm{~nm}$ learnt from atomic force microscopy (AFM) analysis (Fig. 1F). $\mathrm{MnO}_{2}$ maintained excellent stability without obvious precipitation even at $4{ }^{\circ} \mathrm{C}$ for a month (Fig. S2B $\dagger$ ).

To testify the feasibility of $\mathrm{MnO}_{2}$ nanosheets as nanocarrier to load DNA scaffold, fluorophore fluorescein, FAM labeled Probes 1 (FAM-Probe 1) were incubated with $\mathrm{MnO}_{2}$ nanosheets. Considering the $\mathrm{Mn}-\mathrm{N}$ coordinate bonding might further increase the binding of DNA scaffold on the surface of $\mathrm{MnO}_{2}$ nanosheets, FAM- $\mathrm{NH}_{2}$-Probe 1 were also introduced as comparision. Utilizing the fluorescence quenching ability of $\mathrm{MnO}_{2}$ nanosheets to FAM in a close range, the loading ability of $\mathrm{MnO}_{2}$ nanosheets to DNA scaffold was evaluated. As shown in Fig. S3A, $\dagger$ with the increase of the ratio between FAM-Probe 1 and $\mathrm{MnO}_{2}$ nanosheets, the signal-to-noise ratio (SNR) determined by the changes of Dox fluorescence became larger, indicating more FAM-Probe 1 were loaded on $\mathrm{MnO}_{2}$ nanosheets and when the concentration of FAM-Probe 1 was $1.67 \mu \mathrm{M}$, the most optimized loading ability was obtained. The same tendency was obtained in the case of $\mathrm{FAM}-\mathrm{NH}_{2}$-Probe 1 (Fig. S3A $\dagger$ ). But it should be noticed that the existence of amino group helped the loading of DNA scaffold on the $\mathrm{MnO}_{2}$ nanosheets. We then further investigated the influence of the presence of cDNA and Dox on the loading of fabricated DNA scaffold on $\mathrm{MnO}_{2}$ nanosheets. As shown in Fig. $\mathrm{S} 3 \mathrm{~B}, \dagger$ the hybridization between FAM- $\mathrm{NH}_{2}$-Probe 1 and cDNA released only a small amount of $\mathrm{FAM}-\mathrm{NH}_{2}$-Probe 1 from $\mathrm{MnO}_{2}$ nanosheets and most of the FAM- $\mathrm{NH}_{2}$-Probe 1-cDNA could adsorb on the surface of $\mathrm{MnO}_{2}$ nanosheets, which provided the good basis for their following applications. The fabrication of $\mathrm{NH}_{2}$-Probe 1-cDNA- 

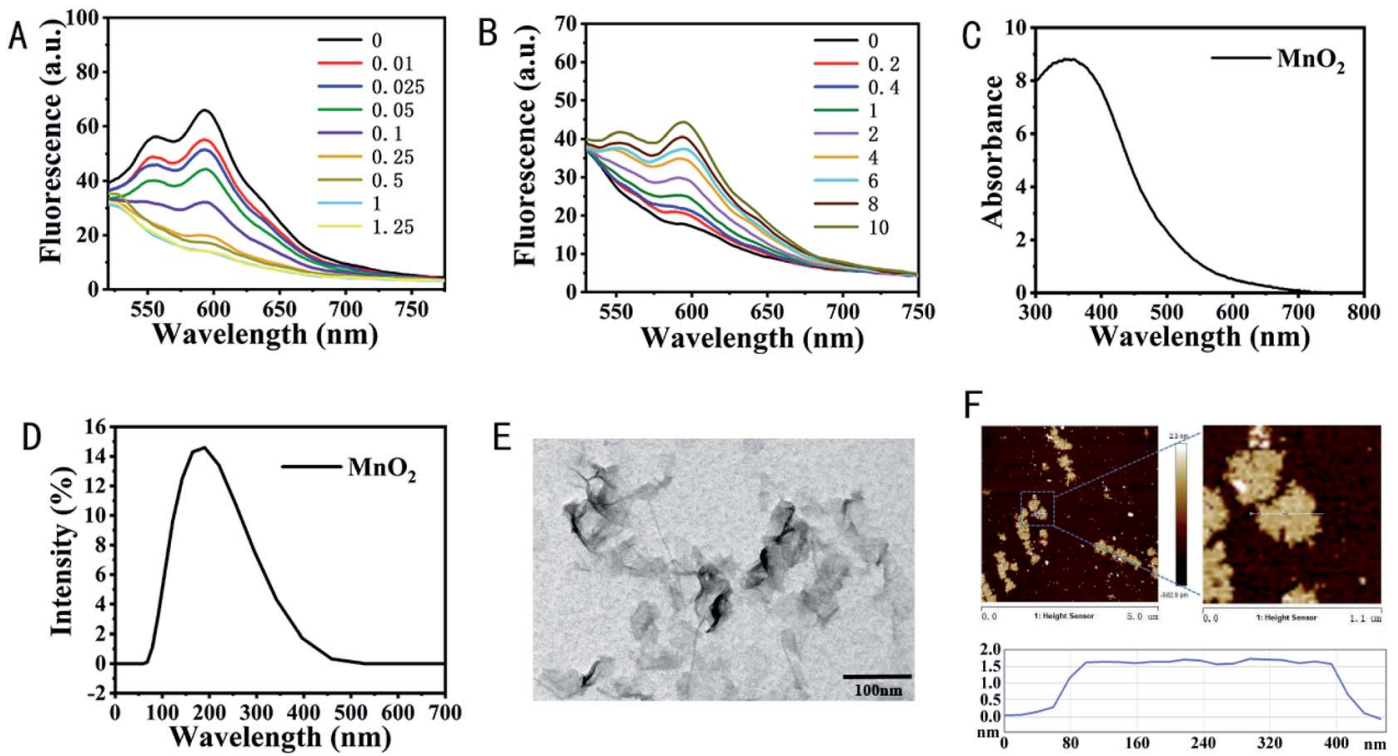

Fig. 1 (A) The fluorescence spectra of $\mathrm{NH}_{2}$-Probe 1-cDNA-Dox with increasing molar ratios between $\mathrm{NH}_{2}$-Probe 1-cDNA and Dox (from top to bottom: $0,0.01,0.025,0.05,0.1,0.25,0.5,1,1.25$, Dox concentration was $1.33 \mathrm{mM}$ ). (B) The fluorescence spectra of $\mathrm{NH}_{2}$-Probe 1 -cDNA-Dox in the presence of different concentrations of $\operatorname{ATP}\left(0,0.2,0.4,1,2,4,6,8,10 \mathrm{mM}\right.$ ). (C) UV-vis spectrum of $\mathrm{MnO}_{2}$ nanosheets. (D) Hydrodynamic diameter of $\mathrm{MnO}_{2}$ nanosheets with Nano ZS90 (Malvern, England). (E) The TEM images of $\mathrm{MnO}_{2}$. The scale bar is $100 \mathrm{~nm}$. (F) The AFM characterization of $\mathrm{MnO}_{2}$ nanosheets.

Dox@ $\mathrm{MnO}_{2}$ was also proved by the changes of zeta potential from $-29.13 \mathrm{mV}$ for $\mathrm{MnO}_{2}$ to $-5.28 \mathrm{mV}$ for $\mathrm{NH}_{2}$-Probe 1-cDNADox and $-30.43 \mathrm{mV}$ for $\mathrm{NH}_{2}$-Probe 1-cDNA-Dox@ $\mathrm{MnO}_{2}$ (Fig. S4A $\dagger$ ). AFM analysis showed the thickness of $\mathrm{MnO}_{2}$ was changed from $1.62 \mathrm{~nm}$ to $2.37 \mathrm{~nm}$ in local area for $\mathrm{NH}_{2}$-Probe 1cDNA-Dox@ $\mathrm{MnO}_{2}$ (Fig. S4B $\dagger$ ).

In addition, $\mathrm{MnO}_{2}$ nanosheets were proved to be used as nanoenzyme for chemodynamic therapy of tumor because $\mathrm{Mn}^{2+}$ can produce $\cdot \mathrm{OH}$ through a Fenton like reaction with the assistance of $\mathrm{HCO}_{3}{ }^{-}$, which raises oxygen levels and depletes the antioxidants. ${ }^{38,39}$ Thus, we evaluated the capacity of $\mathrm{NH}_{2}$ Probe 1-cDNA-Dox@ $\mathrm{MnO}_{2}$ to produce $\cdot \mathrm{OH}$ in the presence of $\mathrm{H}_{2} \mathrm{O}_{2}, \mathrm{HCO}_{3}{ }^{-}$and GSH using methylene blue (MB) as an indicator. $\cdot \mathrm{OH}$ induced degradation of $\mathrm{MB}$ was monitored by the change of absorbance at $665 \mathrm{~nm}$. As shown in Fig. 2A, the absorbance of $\mathrm{MB}$ was significantly decreased when $\mathrm{NH}_{2}$-Probe 1-cDNA-Dox@ $\mathrm{MnO}_{2}$ were incubated with $\mathrm{H}_{2} \mathrm{O}_{2}$, showing the production of $\cdot \mathrm{OH}$. Such absorbance of $\mathrm{MB}$ was further decreased with the addition of GSH, which might come from the more $\mathrm{Mn}^{2+}$ formation and more $\cdot \mathrm{OH}$ production, presenting the potential application of $\mathrm{NH}_{2}$-Probe 1-cDNA-Dox@ $\mathrm{MnO}_{2}$ nanocomplex for the combined therapy of CT and CDT.

\subsection{GSH and ATP dual-responsive Dox release from $\mathrm{NH}_{2}-$ Probe 1-cDNA-Dox $/ \mathrm{MnO}_{2}$}

To evaluate the activatable Dox release and MRI signal, the corresponding roles of GSH and ATP were studied. It is reported that the GSH concentration inside the cells is about $1 \times 10^{-3}$ to $10 \times 10^{-3} \mathrm{M}^{40}$ as compared with $2 \times 10^{-6}$ to $40 \times 10^{-6} \mathrm{M}$ in blood and other body fluids..$^{41}$ The concentration of GSH in cancer cells is 100 - to 1000 -fold higher than that in the blood, and in a tumor mass. It is also markedly (100-fold) higher than the extracellular level, which has been designed for the delivery of drugs and as imaging agents. ${ }^{42}$ Firstly, to evaluate the ATPresponsive Dox release characteristics, $\mathrm{NH}_{2}$-Probe 1-cDNA-Dox was incubated at different concentrations of ATP $(0,0.2,0.4$, $1,2,4,6,8,10 \mathrm{mM})$, respectively. Among them, $0.4 \mathrm{mM}$ and $4 \mathrm{mM}$ ATP represented the typical ATP level in the extracellular fluid and intracellular cytosol. ${ }^{43}$ The binding between ATP and its aptamer would change the structure of ATP aptamer and destroy the duplex, leading to the release of Dox from $\mathrm{NH}_{2}$ Probe 1-cDNA-Dox. Such changes could be monitored by the Dox fluorescence. As mentioned in Fig. 1B, a remarkable fluorescence recovery was observed with the increase of ATP concentration, indicating an ATP-triggered Dox release of our designed DNA scaffold. However, in the case of $\mathrm{NH}_{2}$-Probe 1cDNA-Dox@ $\mathrm{MnO}_{2}$, only the presence of ATP could only release a small amount of Dox, which might come from the interference of $\mathrm{MnO}_{2}$ nanosheets on the binding between ATP and its aptamer (Fig. 2B). Similarly, the existence of GSH could only destroy the structure of $\mathrm{MnO}_{2}$ and release $\mathrm{NH}_{2}$-Probe 1-cDNADox, but no released Dox could be observed. Dox could only be released from $\mathrm{NH}_{2}$-Probe 1-cDNA-Dox@ $\mathrm{MnO}_{2}$ with $\mathrm{GSH}$ and ATP co-existence (Fig. 2B).

To further investigate the in vitro release profiles of $\mathrm{NH}_{2}$ Probe 1-cDNA-Dox@ $\mathrm{MnO}_{2}$, the releasing buffer solutions containing $5 \mathrm{mM}$ HEPES, $137 \mathrm{mM} \mathrm{NaCl}, 10 \mathrm{mM} \mathrm{MgCl} 2,10 \mathrm{mM}$ ATP and $10 \mathrm{mM} \mathrm{GSH}$ (pH 7.0 or 5.0) were prepared. The Dox release was determined based on the linear fitting curves of Dox (Fig. 2C). As shown in Fig. 2D, with a releasing buffer of pH 7.0, only $10.2 \%$ of Dox was released from $\mathrm{NH}_{2}$-Probe 1-cDNADox@ $\mathrm{MnO}_{2}$ in the first 50 min and $19.25 \%$ was released within 

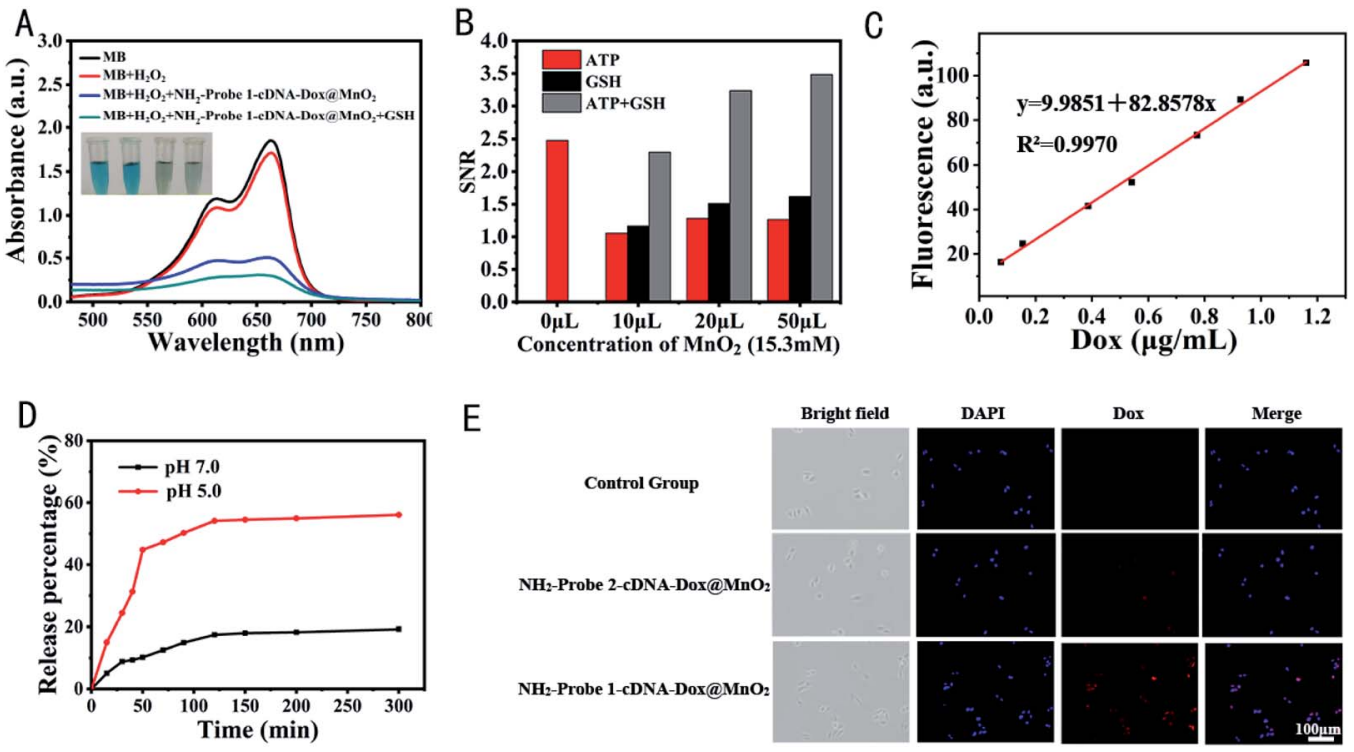

Fig. 2 (A) UV-vis spectra and photos (inset) of MB aqueous solutions treated by different methods. $\left[\mathrm{NaHCO}_{3}\right]=25 \mathrm{mM},\left[\mathrm{H}_{2} \mathrm{O}_{2}\right]=8 \mathrm{mM},[\mathrm{GSH}]=$ $1 \mathrm{mM}, \mathrm{MnO}_{2}=20 \mu \mathrm{L}(15.3 \mathrm{mM} \mathrm{Mn})$. OH-induced $\mathrm{MB}\left(10 \mu \mathrm{g} \mathrm{mL}{ }^{-1}\right)$ degradation was monitored by the change in absorbance at $665 \mathrm{~nm}$. (B) The effect of the presence of GSH and ATP on the release of Dox from $\mathrm{NH}_{2}$-Probe 1-cDNA-Dox@MnO 2 nanocomplex. (C) Linear equation of Dox ranging from 0 to $1.2 \mu \mathrm{g} \mathrm{mL}^{-1}$. (D) In vitro release profiles of Dox from $\mathrm{NH}_{2}$-Probe 1-cDNA-Dox@MnO 2 ( $\mathrm{pH} 7.0 \mathrm{or} \mathrm{pH} 5.0,5 \mathrm{mM} \mathrm{HEPES}, 137 \mathrm{mM}$ $\mathrm{NaCl}, 10 \mathrm{mM} \mathrm{MgCl}_{2}, 10 \mathrm{mM} \mathrm{ATP}$ and $10 \mathrm{mM} \mathrm{GSH}$ ) at $37^{\circ} \mathrm{C}$. (E) Cell uptake of MDA-MB-231 cells after incubation with the NH $\mathrm{N}_{2}-\mathrm{Probe}_{2}-\mathrm{CDNA}-$ Dox@ $\mathrm{MnO}_{2}, \mathrm{NH}_{2}$-Probe 1-cDNA-Dox@ $\mathrm{MnO}_{2}$ or fresh medium (control group) for the same time. Scale bar: $100 \mu \mathrm{m}$.

$300 \mathrm{~min}$. When $\mathrm{pH}$ of the buffer was adjusted to 5.0, the release of Dox was dramatically accelerated. It was showed that about $44.83 \%$ of Dox was released from $\mathrm{NH}_{2}$-Probe 1-cDNA-
Dox@ $\mathrm{MnO}_{2}$ in the first 50 min and more than $56.1 \%$ was released within $300 \mathrm{~min}$.

The intracellular delivery of $\mathrm{NH}_{2}$-Probe 1-cDNA-Dox@ $\mathrm{MnO}_{2}$ in MDA-MB-231 cells was also explored. As shown in Fig. 2E, after
A

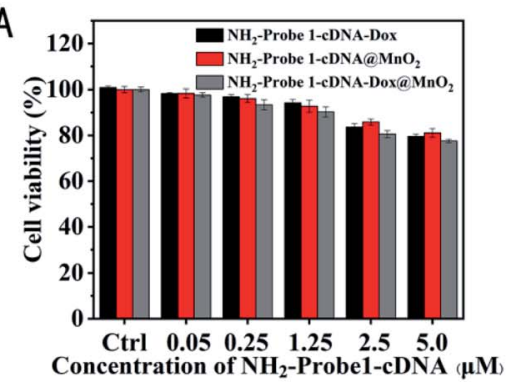

B

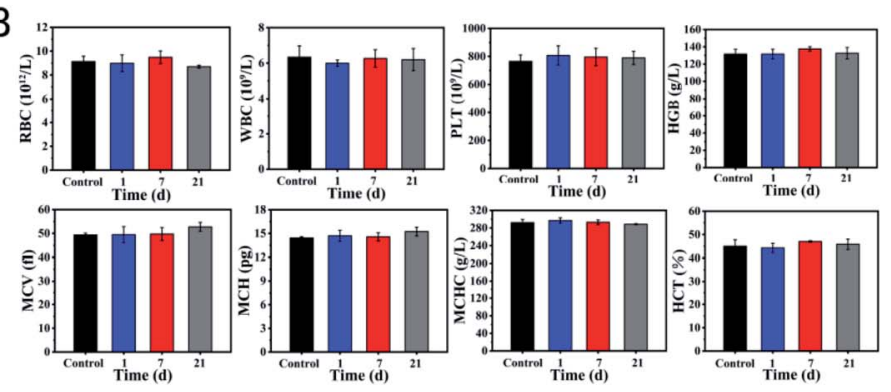

C
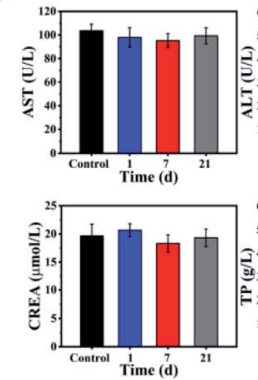
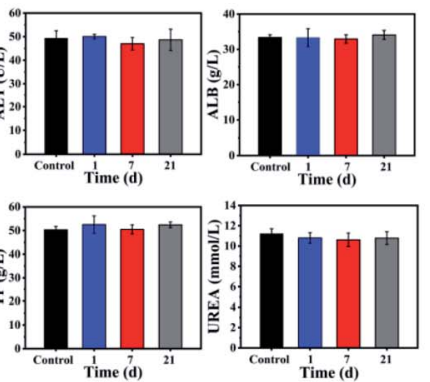

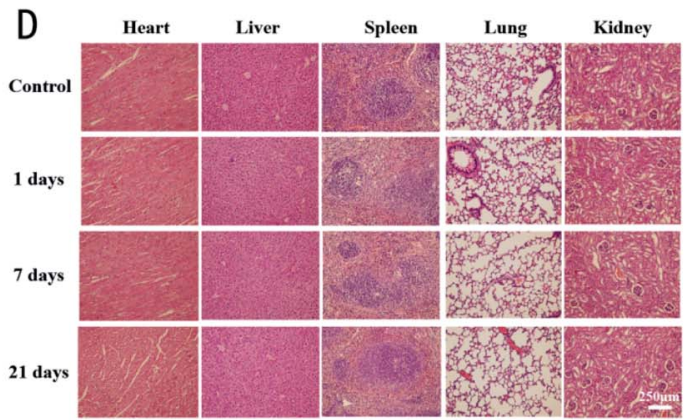

Fig. 3 (A) $\mathrm{NIH}-3 \mathrm{~T} 3$ cell viabilities after incubation with $\mathrm{NH}_{2}$-Probe 1-cDNA-Dox, $\mathrm{NH}_{2}-$ Probe 1-cDNA@MnO 2 and $\mathrm{NH}_{2}-\mathrm{Probe}_{1}$-cDNADox@ $\mathrm{MnO}_{2}$ for $24 \mathrm{~h}$. Mouse serum blood routine analysis (B) and biochemistry analysis (C) after tail vein injection of $\mathrm{NH}_{2}-\mathrm{Probe}_{1-\mathrm{cDNA}-}$ Dox@ $\mathrm{MnO}_{2}$ with normal saline as control. (D) Comparison of tissue structure of heart, liver, spleen, kidney and lung of mice injected with $\mathrm{NH}_{2}-$ Probe 1-cDNA-Dox@ $\mathrm{MnO}_{2}$ nanocomplex for 1, 7 and 21 days and control group (HE staining, scale bar: $\left.250 \mu \mathrm{m}\right)$. 
A

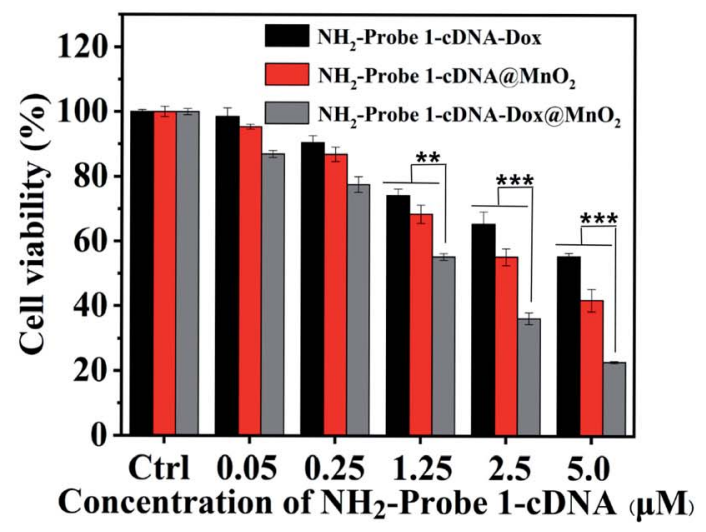

B

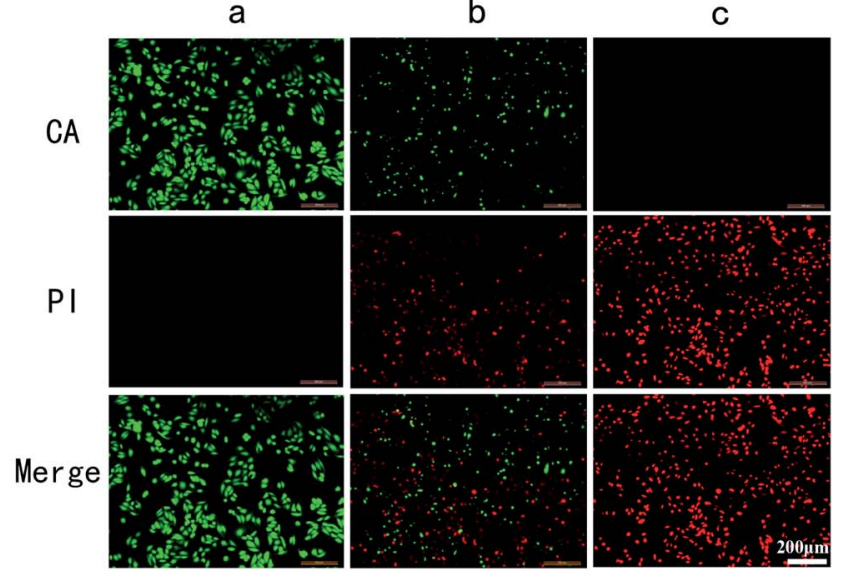

Fig. 4 (A) MDA-MB-231 cell viabilities after incubation with $\mathrm{NH}_{2}$-Probe 1-cDNA-Dox, $\mathrm{NH}_{2}-\mathrm{Probe}_{1-c D N A @ M n O}$ and $\mathrm{NH}_{2}-\mathrm{Probe}_{1-c D N A-D o x @ M n O}$ for $24 \mathrm{~h}$. ${ }^{* *} p<0.01, * * * p<0.001$. (B) Fluorescence images of CA/PI-co-stained MDA-MB-231 cells treated with different groups (a, b and $c$ represent fresh medium, $\mathrm{NH}_{2}$-Probe 1-cDNA $\left(\mathrm{MnO}_{2}\right.$ and $\mathrm{NH}_{2}$-Probe1-cDNA-Dox $\left(\mathrm{MnO}_{2}\right)$ at equivalent concentrations of $\mathrm{Mn}^{2+}$ in $\mathrm{L}-15 \mathrm{media}$. Scale bar: $200 \mu \mathrm{m}$.

incubation for two hours, the red fluorescence of Dox could be observed in the MDA-MB-231 cells, which well overlapped with the blue fluorescence of the nucleus, showing the accumulation of
Dox into the nuclei. Additionally, the presence of AS1411 aptamer favored the Dox delivery to tumor cells benefitting from the nucleolin-mediated endocytosis with the help of AS1411 aptamer.
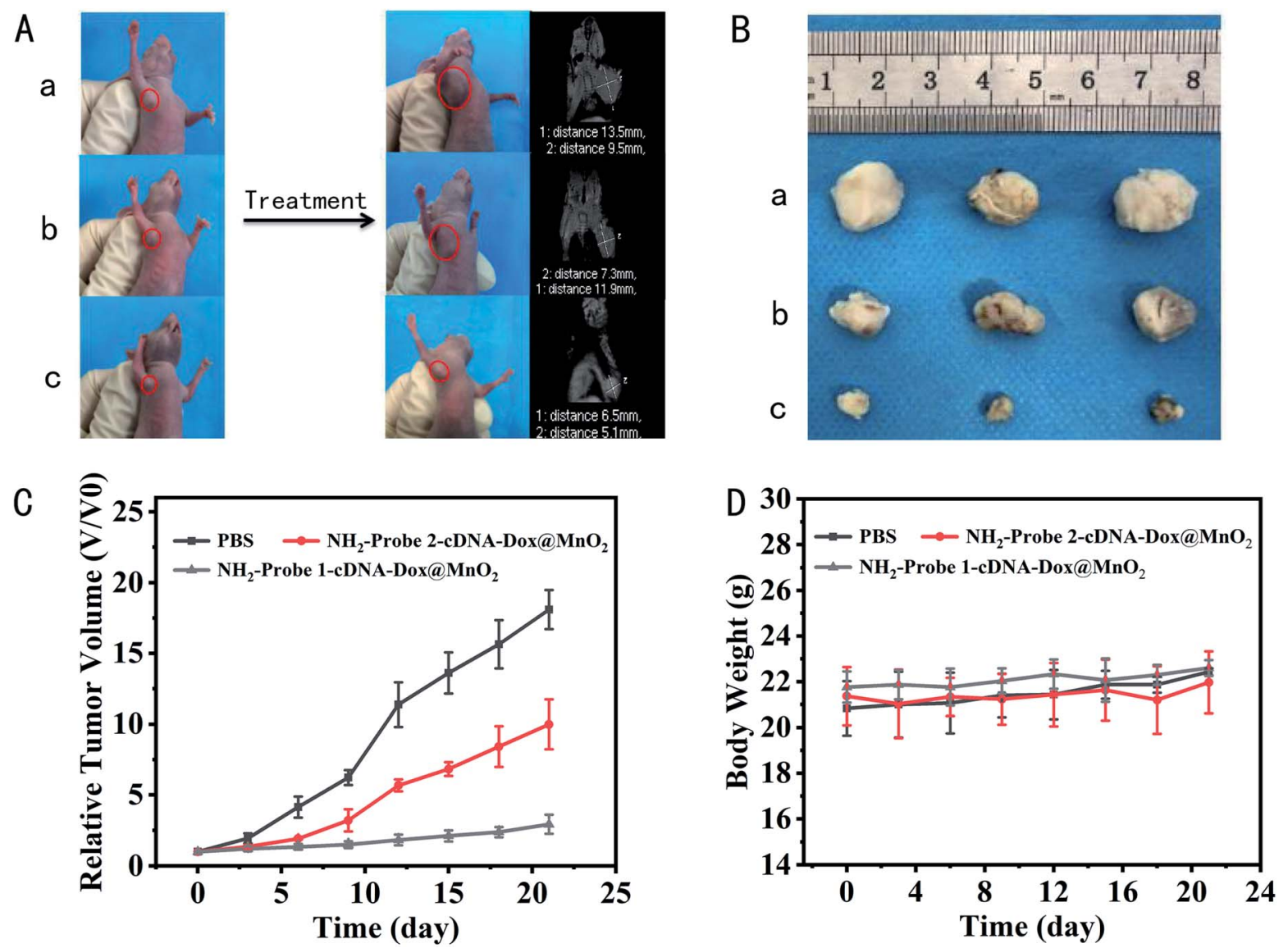

Fig. 5 In vivo tumor-targeted therapy. (A) Representative photographs and representative MRI images of mice from different groups taken at the 21st day. The red circles indicate tumor. ( $\mathrm{a}, \mathrm{b}$ and $\mathrm{c}$ represent tumor bearing mice treated with $\mathrm{PBS}_{1} \mathrm{NH}_{2}-\mathrm{Probe}_{2}-\mathrm{cDNA}^{-\mathrm{D} o x @ M n O} \mathrm{O}_{2}$ and $\mathrm{NH}_{2}-$ Probe 1-cDNA-Dox@ $\mathrm{MnO}_{2}$, respectively). (B) On day 21 after treatment, the tumor size of the tumor-bearing nude mice in different treatment groups. (C) Tumor growth curve of nude mice bearing tumor in different treatment groups. (D) Weight change curve of mice in different treatment groups during treatment. 
Taken together, our fabricated $\mathrm{NH}_{2}$-Probe 1-cDNADox@ $\mathrm{MnO}_{2}$ nanocomplex presented tumor microenvironment related multicomponent response, showing their promising potential for the specific MRI and combination therapy of CT and CDT of tumor.

\subsection{Antitumor efficacy in vitro and in vivo}

To explore their potential for the application of the tumor cell growth inhibition, MDA-MB-231 and NIH-3T3 cells were treated with different concentrations of $\mathrm{NH}_{2}$-Probe 1-cDNA-Dox, $\mathrm{NH}_{2}$ Probe 1-cDNA@ $\mathrm{MnO}_{2}$ and $\mathrm{NH}_{2}$-Probe 1-cDNA-Dox@ $\mathrm{MnO}_{2}$, respectively. The cell viabilities were determined by MTT assay. As expected, no obvious cytotoxicity was observed for the above complex to NIH-3T3 cells, showing their good biocompatibility to normal cells (Fig. 3A). Furthermore, the hematological and biochemical analyses as well as pathological section analysis also testified the excellent biocompatibility of our fabricated $\mathrm{NH}_{2}$-Probe 1-cDNA-Dox@ $\mathrm{MnO}_{2}$. The results of blood routine (Fig. 3B) and blood biochemical (Fig. 3C) tests showed no obvious abnormality compared with the normal control group, showing no obvious acute toxicity of $\mathrm{NH}_{2}$-Probe 1-cDNADox@ $\mathrm{MnO}_{2}$ to liver and kidney. What's more, we compared the histological structures of the heart, liver, spleen, kidneys and lungs dissected from the mice without and post-injection of $\mathrm{NH}_{2}$-Probe 1-cDNA-Dox@ $\mathrm{MnO}_{2}$ for 1, 7, and 21 day. As shown in
Fig. 3D, the structures of the myocardium, hepatic lobules, splenic sinuses, glomeruli, and alveoli were clearly visible, suggesting no acute or chronic tissue damage after the $\mathrm{NH}_{2}$ Probe 1-cDNA-Dox@ $\mathrm{MnO}_{2}$ injection.

But for MDA-MB-231 breast cancer cells, all of $\mathrm{NH}_{2}$-Probe 1cDNA-Dox, $\mathrm{NH}_{2}$-Probe 1-cDNA@ $\mathrm{MnO}_{2}$ and $\mathrm{NH}_{2}$-Probe 1-cDNADox@ $\mathrm{MnO}_{2}$ presented a concentration-dependent cytotoxicity (Fig. 4A). Furthermore, the lowest cell viability in $\mathrm{NH}_{2}$-Probe 1cDNA-Dox@ $\mathrm{MnO}_{2}$ group indicated the excellent effect of the combination therapy of CT and CDT. In order to visualize living and dead cells, the cells after different treatments were costained with CA and PI solution. Living cells are dyed green and dead cells are dyed red, respectively. The methyl acetate of CA has high lipophilicity, which makes it permeable through the cell membrane. Although CA itself is not a fluorescent molecule, CA can remove the acetyl methoxymethyl ester (AM) group through the action of esterase in living cells, and the resulting calcein can emit strong green fluorescence. Therefore, living cells can be stained by CA with green emission. On the other hand, PI, as a nuclear dye, can not pass through the living cell membrane, but it can pass through the disordered region of the dead cell membrane and reach the nucleus, and embed the DNA double helix of the cell to produce red fluorescence. ${ }^{\mathbf{4 4}}$ Learnt from Fig. 4B, green fluorescence emission and almost no red fluorescence emission showed the excellent growth
A

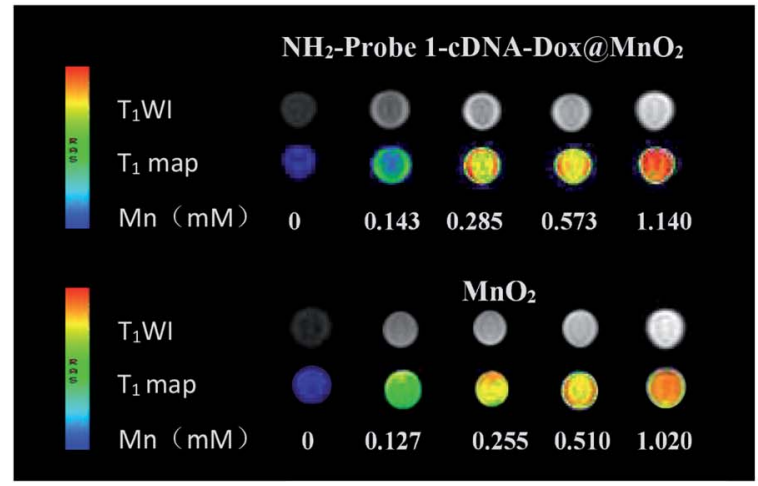

C

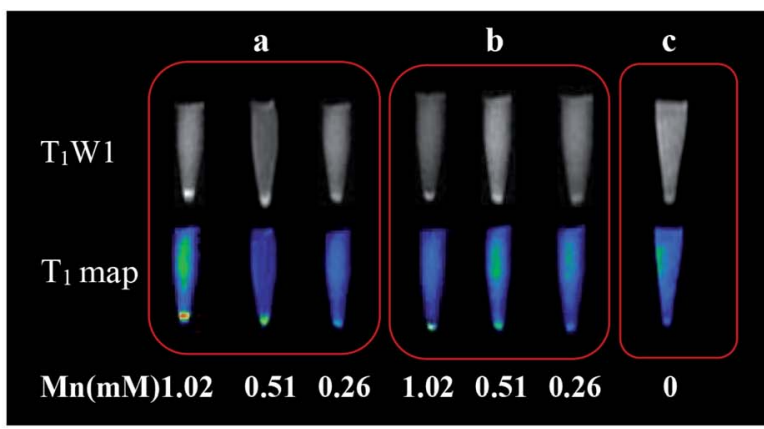

B
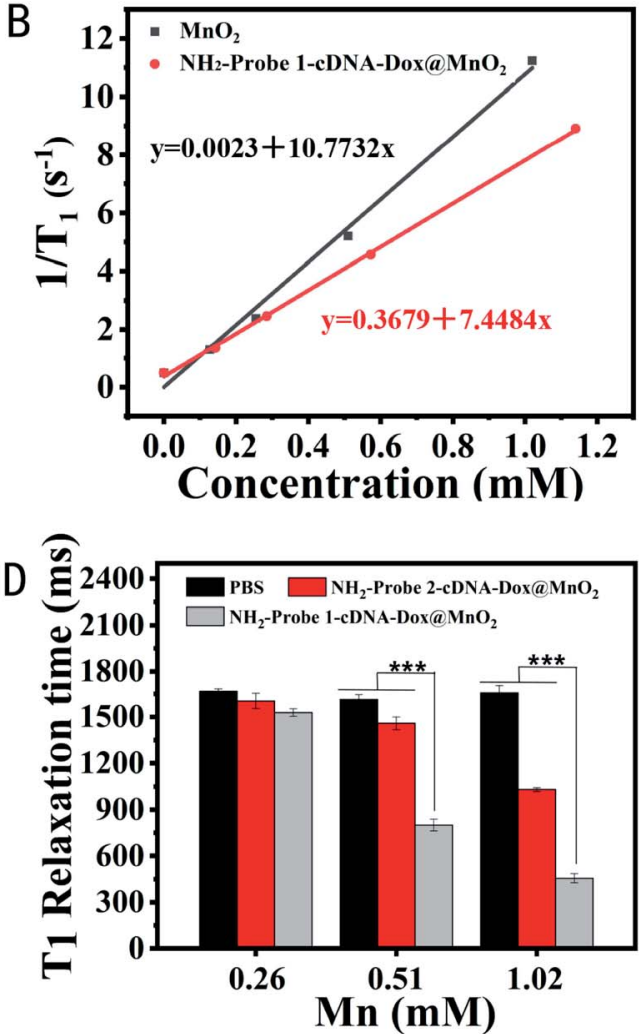

Fig. 6 (A) $T_{1}$-weighted phantom images of $\mathrm{MnO}_{2}$ and $\mathrm{NH}_{2}$-Probe 1-cDNA-Dox@MnO 2 at different $\mathrm{Mn}^{2+}$ concentrations using a $3.0 \mathrm{~T}$ MR scanner. (B) $T_{1}$ relaxivity curves of $\mathrm{MnO}_{2}$ and $\mathrm{NH}_{2}$-Probe 1-cDNA-Dox@MnO 2 . (C) $T_{1}$-weighted and $T_{1}$-map images as well as the corresponding $T_{1}$ relaxation time of MDA-MB-231 cells treated with different concentrations of $\mathrm{NH}_{2}-$ Probe $1-\mathrm{CDNA}-\mathrm{Dox}\left(\mathrm{MnO}_{2}, \mathrm{NH}_{2}-\mathrm{Probe}^{2}-\mathrm{cDNA}-\right.$ Dox@ $\mathrm{MnO}_{2}$ and PBS. (D) The corresponding signal intensities of (C). 
situation in control group. But with the addition of $\mathrm{NH}_{2}$-Probe 1cDNA@ $\mathrm{MnO}_{2}$ or $\mathrm{NH}_{2}$-Probe 1-cDNA-Dox@ $\mathrm{MnO}_{2}$, less green fluorescence emission and more red fluorescence emission were observed, showing their cytotoxicity to tumor cells. Furthermore, almost no green fluorescence emission could be found with the treatment of $\mathrm{NH}_{2}$-Probe 1-cDNA-Dox@ $\mathrm{MnO}_{2}$, displaying their higher cytotoxic activity towards the tumor cells.

The excellent tumor cell inhibition of the fabricated nanocomplex in vitro promoted us to explore their antitumor efficacy in vivo. After treatment, tumor growth was almost completely suppressed in mice treated with $\mathrm{NH}_{2}$-Probe 1-cDNADox@ $\mathrm{MnO}_{2}$, and more significantly than the mice treated with PBS and $\mathrm{NH}_{2}$-Probe 2-cDNA-Dox@ $\mathrm{MnO}_{2}$. MRI scans taken on the last day further confirmed these changes (Fig. 5A). The mice were killed at the 21st day and the tumor sizes in the different groups were compared. The tumors in the $\mathrm{NH}_{2}$-Probe 1-cDNA-
Dox@ $\mathrm{MnO}_{2}$ group showed almost no significant enlargement. In contrast, tumor growth in the $\mathrm{NH}_{2}$-Probe 2-cDNADox@ $\mathrm{MnO}_{2}$ group was relatively faster, suggesting that more chemotherapy drugs were concentrated in the tumor region due to antibody target recognition (Fig. 5B). In addition, tumors in mice treated with $\mathrm{PBS}$ and $\mathrm{NH}_{2}$-Probe 2-cDNA-Dox@ $\mathrm{MnO}_{2}$ showed rapid growth during subsequent treatment (Fig. 5C). More importantly, there was no significant weight loss or animal death in all three groups during the entire monitoring period, indicating that the prepared nanomedicine showed excellent therapeutic efficacy without significant side effects on the tested animals (Fig. 5D).

\subsection{In vitro and in vivo enhanced $\mathrm{MR}$ imaging}

To explore the specific MRI ability of $\mathrm{NH}_{2}$-Probe 1-cDNADox@ $\mathrm{MnO}_{2}$ to tumor cells in vitro and in vivo, its $r_{1}$ relaxivity in

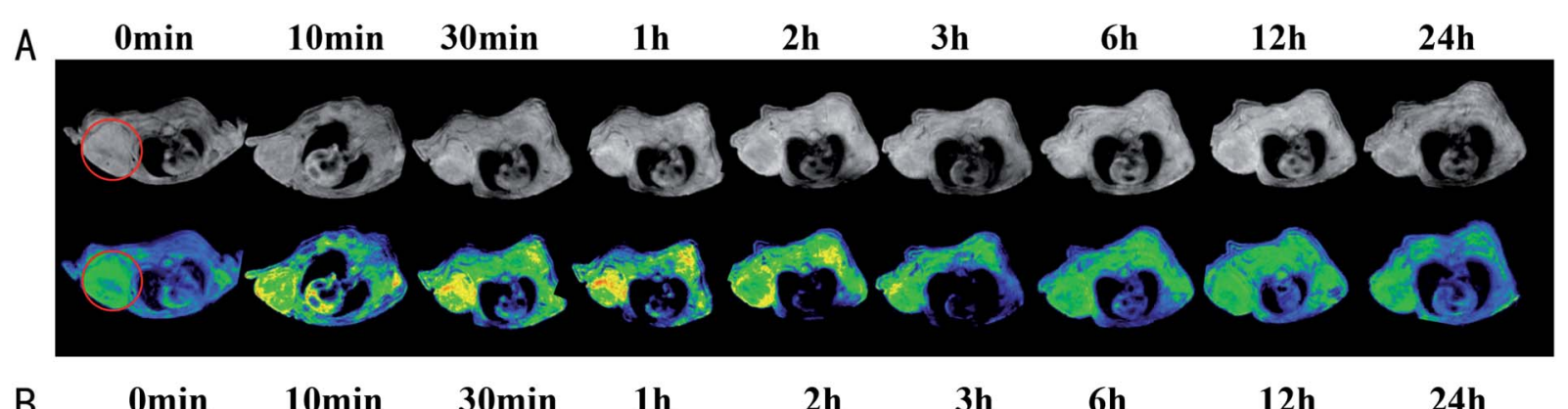

B

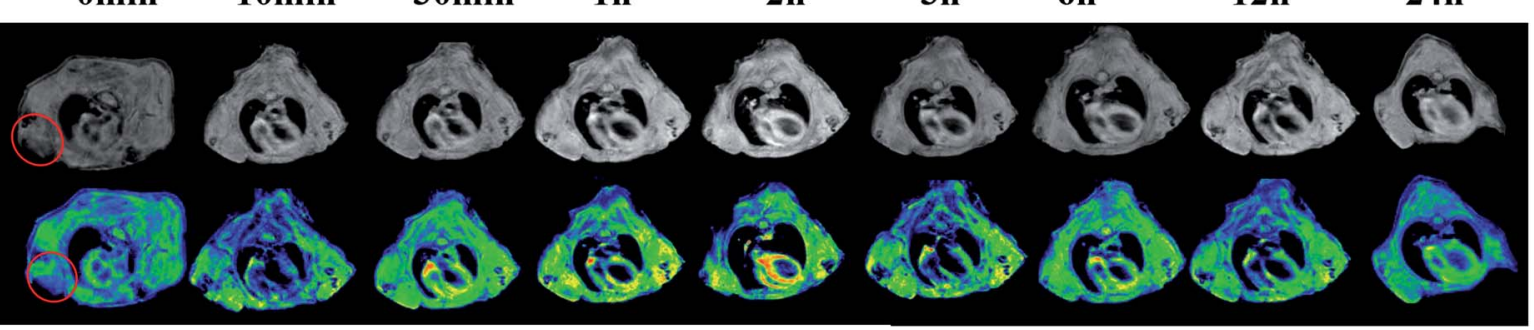

C

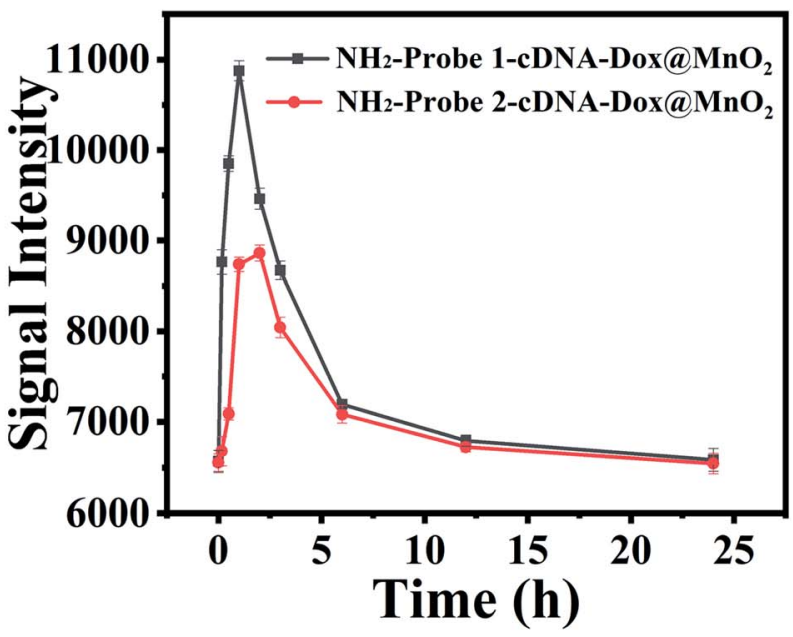

D

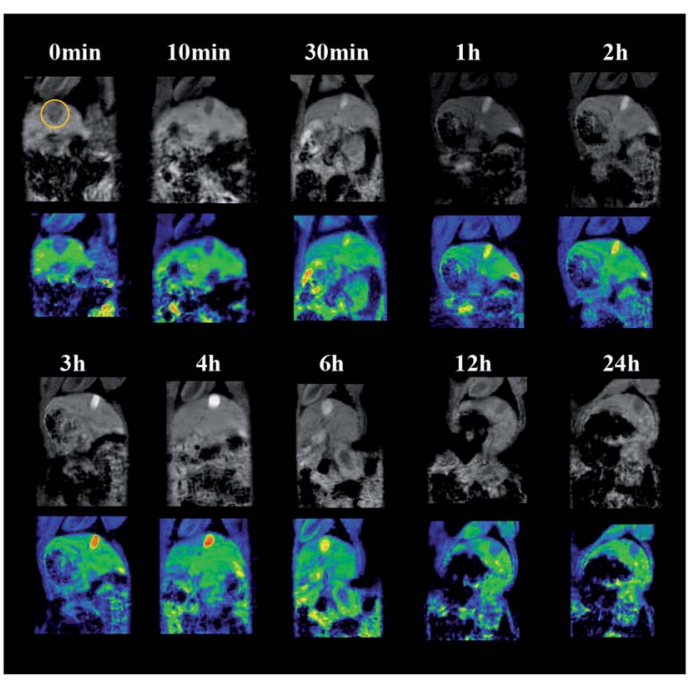

Fig. $7 \quad T_{1}$-weighted and $T_{1}$ pseudocolor images of tumor-bearing nude mice before and after injection of (A) NH $\mathrm{N}_{2}-\mathrm{Probe}$ - $-\mathrm{cDNA}-\mathrm{Dox} @ \mathrm{MnO} 2$ and (B) $\mathrm{NH}_{2}$-Probe 2-cDNA-Dox@ $\mathrm{MnO}_{2}$ (circles in red indicate tumors). (C) The corresponding signal curve of tumor in different treatment groups over time. (D) $T_{1}$-weighted and $T_{1}$ pseudocolor images of mice bearing breast carcinoma pre- and post-injection of $\mathrm{NH}_{2}-\mathrm{Probe} 1$-cDNADox@ $\mathrm{MnO}_{2}$. The yellow circle indicates the gallbladder. 
the presence of $10 \mathrm{mM}$ GSH was first determined. As shown in Fig. 6A and $\mathrm{B}$, the $r_{1} \mathrm{MRI}$ relaxivity values of $\mathrm{MnO}_{2}$ and $\mathrm{NH}_{2}$ Probe 1-cDNA-Dox@ $\mathrm{MnO}_{2}$ were $10.77 \mathrm{mM}^{-1} \mathrm{~s}^{-1}$ and 7.45 $\mathrm{mM}^{-1} \mathrm{~s}^{-1} \mathrm{Mn}$, respectively. The MRI signal intensity of $\mathrm{NH}_{2}$ Probe 1-cDNA-Dox@ $\mathrm{MnO}_{2}$ within 30 day period presented unnoticeable changes, providing excellent basis for their use as MRI contrast agent (Fig. S5 $\dagger$ ). Then, their performance for the specific MRI of MDA-MB-231 cells was evaluated. It was showed that the designed $\mathrm{NH}_{2}$-Probe 1-cDNA-Dox@ $\mathrm{MnO}_{2}$ nanocomplex could target MDA-MB-231 cells visualized by MR imaging with the help of AS1411 aptamer and GSH-activated MRI signal (Fig. 6C). At the same $\mathrm{MnO}_{2}$ concentration, the signal intensity of the targeted group ( $\mathrm{NH}_{2}$-Probe 1-cDNA-Dox@ $\left.\mathrm{MnO}_{2}\right)$ was significantly higher than that of the non-targeted group $\left(\mathrm{NH}_{2}-\right.$ Probe 2-cDNA-Dox@ $\mathrm{MnO}_{2}$ ) and the control group (PBS), indicating the higher accumulation amount of nanocomplex on tumor cells with the help of AS1411 aptamer (Fig. 6D).

Later, such specific MRI of tumor cells was expanded to breast carcinoma bearing $\mathrm{BALB} / \mathrm{c}$ nude mice. $\mathrm{NH}_{2}$-Probe 1cDNA-Dox@ $\mathrm{MnO}_{2}$ or $\mathrm{NH}_{2}$-Probe 2-cDNA-Dox@ $\mathrm{MnO}_{2}$ was injected into the nude mouse model via tail vein and the $T_{1^{-}}$ weighted MRI scans were conducted at scheduled time points. As shown in Fig. 7A and B, the tumors both exhibited contrastenhanced regions after post-injection of $\mathrm{NH}_{2}$-Probe 1-cDNADox@ $\mathrm{MnO}_{2}$ or $\mathrm{NH}_{2}$-Probe 2-cDNA-Dox@ $\mathrm{MnO}_{2}$. The $T_{1} \mathrm{MR}$ signal in the tumor gradually brightens over the first 3 hours and then weakens over time. However, it should be noted that the $T_{1}$ signal of $\mathrm{NH}_{2}$-Probe 1-cDNA-Dox@ $\mathrm{MnO}_{2}$ was significantly brighter than that observed after injection of $\mathrm{NH}_{2}$-Probe 2-cDNA-Dox@ $\mathrm{MnO}_{2}$ at the same time. Benefit from the targeting ability of the AS1411 aptamer (Fig. 7C). Meanwhile, we found a strong enhanced signal from the gallbladder, indicating the excretion of the reduced $\mathrm{Mn}^{2+}$ ions might mainly via hepatobiliary system (Fig. 7D), which was consistent with our previous report. $^{32}$ The blood half-life time was determined to be 1.65 h (Fig. S6†).

\section{Conclusions}

Here, we propose a dual-sensitive nanoplatform for the controlled drug delivery and activatable MRI and CT \& CDT combined therapy of tumor based on DNA aptamers and $\mathrm{MnO}_{2}$ nanosheets. The cleaver DNA design of the integration of targeting molecule and drug loading molecule simplified the preparation procedure. The $\mathrm{MnO}_{2}$ nanosheets as nanocarrier and AS1411 aptamer as targeting molecule favored the efficient drug delivery to breast cancer cells. Then, the Dox release triggered by the co-existence of ATP and GSH further increase the on-demand drug delivery accurately and therapeutic efficacy. In addition, $\mathrm{Mn}^{2+}$ mediated Fenton-like reactions for CDT, which synergistically enhanced the therapy effect. More importantly, MRI from $\mathrm{Mn}^{2+}$ realized the real-time diagnosis and monitoring of tumor changes after the drug intervention. This strategy might provide a new idea for the design of theranostic nanoplatform for the more accurate diagnosis and treatment of tumor. In the future study, we will try to evaluate the therapy effect of our fabricated nanocomposites on advanced tumor model, which is more meaningful for their later clinical transformation.

\section{Author contributions}

Mingming Zhao: data curation, formal analysis, methodology, investigation, writing - original draft. Xiaoxi Song: investigation. Jiahui Lu: methodology, investigation. Siwen Liu: validation. Xuan Sha: methodology, investigation. Qi Wang: software, formal analysis. $\mathrm{Xu}$ Cao: scheme drawing. Kai Xu: funding acquisition, supervision. Jingjing Li: conceptualization, supervision, resources, funding acquisition, writing - review \& editing. All the authors have approved the manuscript.

\section{Conflicts of interest}

There are no conflicts of interest to declare.

\section{Acknowledgements}

This work was supported by the National Natural Science Foundation of China (81771904), the Natural Science Foundation of Jiangsu Province for the Excellent Young Scholars (BK20170054), Qing Lan Project, the Peak of Six Talents of Jiangsu Province (WSN-112), Jiangsu Provincial Medical Youth Talent (QNRC2016776), Six one project of Jiangsu Province (LGY2018083), Postgraduate Research \& Practice Innovation Program of Jiangsu Province (KYCX21_2737, KYCX21_2724).

\section{Notes and references}

1 R. Barman, A. Nain and S. Jain, J. Mater. Chem. B, 2018, 6, 2368-2384.

2 R. Cheng, L. Liu, Y. Xiang, L. Deng, H. Zhang, H. A. Santos and W. Cui, Biomaterials, 2020, 232, 119706.

3 X. Nguyen, L. Huang, M. Gauthier, G. Yang and Q. Wang, Nanomedicine, 2016, 11, 1169-1185.

4 E. Bagheri, L. Ansari, K. Abnous, S. M. Taghdisi, F. Charbgoo, M. Ramezani and M. Alibolandi, J. Controlled Release, 2018, 277, 57-76.

5 J. Amina and B. Guo, Int. J. Nanomed., 2020, 15, 9823-9857. 6 J. Liu, J. Dong, T. Zhang and Q. Peng, J. Controlled Release, 2018, 286, 64-73.

7 S. Er, U. Laraib, R. Arshad, S. Sargazi, A. Rahdar, S. Pandey, V. Thakur and A. M. Díez-Pascual, Nanomaterials, 2021, 11(11), 3002-3036.

8 S. Timin, M. M. Litvak, D. A. Gorin, E. N. AtochinaVasserman, D. N. Atochin and G. B. Sukhorukov, Adv. Healthcare Mater., 2017, 1700818.

9 E. Levy-Nissenbaum, A. F. Radovic-Moreno, A. Z. Wang, R. Langer and O. C. Farokhzad, Trends Biotechnol., 2018, 26(8), 442-449.

10 X. Liao, E. Y. Chuang, C. C. Lin, Y. C. Ho, K. Ju. Lin, P. Y. Cheng, K. J. Chen, H. J. Wei and H. W. Sung, J. Controlled Release, 2015, 208, 42-51.

11 J. Bates, D. A. Laber, D. M. Miller, S. D. Thomas and J. O. Trent, Exp. Mol. Pathol., 2009, 86, 151-164. 
12 C. Mi, S. D. Thomas, X. H. Xu, L. K. Casson, D. M. Miller and P. J. Bates, J. Biol. Chem., 2003, 278, 8572-8579.

13 L. Dai, D. Wei, J. Zhang, T. Shen, Y. Zhao, J. Liang, W. Ma, L. Zhang, Q. Liu and Y. Zheng, Cell Proliferation, 2021, e13130.

14 Z. Chen, Y. Peng, Y. Li, X. Xie, X. Wei, G. Yang, H. Zhang, N. Li, T. Li, X. Qin, S. Li, C. Wu, F. You, H. Yang and Y. Liu, ACS Nano, 2021, 15, 16683-16696.

15 K. Han, W. Zhang, J. Zhang, Z. Ma and H. Han, Adv. Healthcare Mater., 2017, 6, 2192-2640.

16 Y. Li, J. Jeon and J. H. Park, Cancer Lett., 2020, 490, 31-43.

17 M. Shahriari, M. Zahiri, K. Abnous, S. Taghdisi, M. Ramezani and M. Alibolandi, J. Controlled Release, 2019, 308, 172-189.

18 M. Sponchioni, P. U. Capasso and D. Moscatelli, Mater. Sci. Eng., C, 2019, 102, 589-605.

19 X. Guo, Y. Cheng, X. Zhao, Y. Luo, J. Chen and W. Yuan, J. Nanobiotechnol., 2018, 16, 74.

20 W. Q. Lim, S. Phua and Y. Zhao, ACS Appl. Mater. Interfaces, 2019, 11, 31638-31648.

21 J. Wang, Z. Wang, J. Yu, A. R. Kahkoska, T. B. Buse and Z. Gu, Adv. Mater., 2020, 32, e1902004.

22 R. Volpatti, M. A. Matranga, A. B. Cortinas, D. Delcassian, K. B. Daniel, R. Langer and D. G. Andersonet, ACS Nano, 2020, 14, 488-497.

23 W. Zhao, Y. Zhao, Q. Wang, T. Liu, J. Sun and R. Zhang, Small, 2019, 15, e1903060.

24 J. Qu, Y. Liang, M. Shi, B. Guo, Y. Gao and Z. Yin, Int. J. Biol. Macromol., 2019, 140, 255-264.

25 W. Chen, C. Cheng and J. I. Zink, ACS Nano, 2019, 13, 12921308.

26 D. Huang, M. Sun, Y. Bu, F. Luo, C. Lin, Z. Lin, Z. Weng, F. Yang and D. Wu, J. Mater. Chem. B, 2019, 7(14), 2330-2337.

27 S. El-Sawy, A. M. Al-Abd, T. A. Ahmed, K. M. El-Sayet and V. P. Torchilin, ACS Nano, 2018, 12, 10636-10664.

28 S. Li, Q. Jiang, S. Liu, Y. Zhang, Y. Tian, C. Song, J. Wang, Y. Zou, G.-J. Anderson, J. Han, Y. Chang, Y. Liu, C. Zhang,
L. Chen, G. Zhou, G. Nie, H. Yan, B. Ding and Y. A. Zhao, Nat. Biotechnol., 2018, 36, 258-264.

29 R. Mo, T. Jiang, R. DiSanto, W. Tai and Z. Gu, Nat. Commun., 2014, 5, 3364.

30 Q. Hu, H. Li, L. Wang, H. Gu and C. Fan, Chem. Rev., 2019, 119, 6459-6506.

31 X. Yang, Q. Tang, Y. Jiang, M. Zhang, M. Wang and L. Mao, J. Am. Chem. Soc., 2019, 141, 3782-3786.

32 M. Shi, S. Wang, S. Zheng, P. Hou, L. Dong, M. He, C. Wu, X. Zhang, F. Zuo, K. Xu and J. Li, Colloids Surf., B, 2020, 185, 110625.

33 S. Zheng, M. Zhang, H. Bai, M. He, L. Dong, L. Cai, M. Zhao, Q. Wang, K. Xu and J. Li, Int. J. Nanomed., 2019, 14, 95139524.

34 F.-R. Balkwill, M. Capasso and T. Hagemann, J. Cell Sci., 2012, 125, 5591-5596.

35 S. Zheng, N. Yu, C. Han, T. Xie, B. Dou, Y. Kong, F. Zuo and M. Shi, Biochem. Biophys. Res. Commun., 2019, 511, 207-213.

36 B. Chaires, J. E. Herrera and M. J. Waring, Biochemistry, 1990, 29, 6145-6153.

37 Z. Xiao, C. Ji, J. Shi, E. M. Pridgen, J. Frieder, J. Wu and O. C. Farokhzad, Angew. Chem., Int. Ed. Engl., 2012, 51, 11853-11857.

38 Z. Qing, A. Bai, L. Chen, S. Xing, Z. Zou, Y. Lei, J. Li, J. Liu and R. Yang, CCS Chem., 2020, 2, 1217-1230.

39 L. Lin, J. Song, L. Song, K. Ke, Y. Liu, Z. Zhou, Z. Shen, J. Li, Z. Yang, W. Tang, G. Niu, H. Yang and X. Chen, Angew. Chem., Int. Ed. Engl., 2018, 57, 4902-4906.

40 C. Hwang, A. J. Sinskey and H. F. Lodish, Science, 1992, 257, 1496-1502.

41 R. Hong, G. Han, J. M. Fernández, B. J. Kim, N. S. Forbes and V. M. Rotello, J. Am. Chem. Soc., 2006, 128, 1078-1079.

42 P. Torchilin, Nat. Rev. Drug Discovery, 2014, 13, 813-827.

43 W. Gorman, E. O. Feigl and C. W. Buffington, Clin. Chem., 2007, 53, 318-325.

44 Y. Wang, J. Chen, X. Liang, H. Han, H. Wang, Y. Yang and Q. Li, Mol. Pharm., 2017, 14, 2323-2332. 